\title{
Tranglations
}

\section{DREAMS AND MYTHS. A STUDY IN RACE PSYCHOLOGY*}

By Dr. Karl ABr.hHam

(IF HERLIN

\author{
Translated by Dr. William A. Winte
}

SLIERINTENIENT OF THF GOVERNMENT HOSPITAL FOR THE INSANE, WASHINGTON, D. C.

\section{I \\ Object and Viewpoint of Psychonnalytic Invistigations According to Fre(d)}

The psychological theories that are associated with the name of S. Freuch reach out into regions of the psychic life of man, which, from outer appearances, have no relation to one another. Freud in common with J. Brener in their "Studien über Hysterie" ( 1895 ) started out from pathological psychic manifestations. The progressive elaboration of the psychoanalytic method repuired a searching study of dreams. ${ }^{1}$ It appeared also that for a full understanding of these phenomena the comparative consideration of certain other phenomena must be taken up. Freurl saw this and drew wider and wider areas of the normal and diseased psychic life into the field of his investigations. So there appeared in the Sammlung kleiner Schriften aur Neurosenlehre (1906) an assortment of studies of hysteria, compulsive ideas, and other psychic disturbances, later the monographs "Über den Witz" (I905), the "Abhandlungen zur Sexualtheorie" (Ig05), and lately the psychological analysis of a poet's works, ${ }^{2}$ which constitutes the first volume of this series. Fretul came to consider these apparently heterogeneous products of man's psyche from a com-

* Traum und Mythus. Fine Studie zur Völkerpsychologie. Schriften zur angewandten Seelenkunde. Leipzig und Wien. Franz Deuticke 1909.

" Die Traumdeutung." Wien und Leipzig, I900 (2 Auf. I909).

" "Der Wahn und die Trïume in W. Jensens' 'Gradiva." WWien und Leipzig, 1907. 
mon viewpoint. They all have in common the relation to the unconscious, to the psychic life of childhood, and to the sexuality; they have in common the tendency to represent a wish of the indiviclual as fulfilled; in common are the means of this representation, which serve to this end.

If who is not acquainted with Frend's writings and those of his followers, will be astonished that one should carnestly seek to place all these expressions near one another under the same viewpoint. He will ask what sort of relations wit has to the unconscious. He will cloubt that a disease can contain a wish-fulfillment for the patient who suffers from it and he will not quite comprehend how one can place poetry parallel in this respect. He will not understand what general relations are supposed to prevail between the dreams of adults and the psyche of the child. Ile will, and this perhaps most, be opposed to the idea that one can ascribe to all these psychological phenomena relations to sexuality. And so the teachings laid down by Freud appear to be full of contradictions and absurdities; they appear as isolated statements without critique to generalize. Consequently one will be inclined to reject, a liminc, the methods of investigation, with the help of which, results like these are obtained..

If I were to attempt here an answer to the different objections I could not avoid a detailed presentation of all of Frend's teachings and would be obliged to considerably overstep the limits of this work. Opportunity will offer, in the course of our inquiry, to touch upon the most important problems to which Freud has devoted his work. In the meantime suffice a reference: All of the psychic phenomena which we above place side by sicle are the products of phantasy. We will not assume, without further demonstration, that as such they present certain analogies among themselves.

There are, besides the products of individual phantasy, also those that cannot be ascribed to such phantasy. I am satisfied at this place to mention myths and legends as structures of such a kind. We do not know who created them, who first related them. In the sagas and legends folk phantasy finds expression.

- This is about the standpoint taken by the medical profession to Freud's teachings. It must be confessed that l'reud's teachings must at first appear strange to the unprejudiced. It should be cmphasized that a wide cleft separates them from traditional psychology. That should be no ground, however, for dismissing them with a shrug of the shotlders or a few witty catch words, as happens on the side of the critics. 
Frend has already made them, to a certain degree, the objects of his inquiries, and in numerous respects disclosed psychological analogies between them and the results of individual phantasy. Recently another author has followed in his tracks. Riklin* has examined into the psychological analogies of the legends of different peoples. The proposed work is an attempt to compare myths with the phenomena of individual psychology, especially with dreams. It will bring out the proof that Freud's teachings, in a wide sense, can be transferred to the psychology of myths, and are even qualified to furnish wholly new gromels for the unclerstanding of the sagas. ${ }^{5}$

Cilildiood Pinatasies in Dreazs and Mytis. Applicition of tile Mish THeory to Mrtis

I will anticipate at once some of the principal evident objections to this undertaking as planned. It will be objected that myths spring from phantasies which operate during the waking state, while dreams owe their origin to sleep and to a conclition of lowered consciousness. Careful consideration shows, however, that this in no way constitutes an important difference. We dream not only during sleep; there are also waking dreams. In these we transfer ourselves into an artificial situation and form the world and our future according to our wishes. That the same tendency dwells in night dreams will very soon be accepted by is. Many people tend, in a surprising degree, to day dreaning; one sees them thus absorbed. Imperceptible gradations lead over here to a pathological activity of phantasy. Children give themselves to such dream-like phantasies very readily. The little boy, in his day dream, is king of a great realm and conquers in bloody battles; or he distinguishes himself as an Indian chief or in some other manner. Pathological grades of absorption in clay dreams are not rare among children. We already see from this

"The announced work of Riklin: "Wunscherfüllung uncl Symbolik im Märchen" (Vol. 2 of this series) appeared after my work was finished. I could, therefore, only make use of a short preliminary communication of the atthor. (Psychiatr-neurol. W'ochenschrift, $1907, \mathrm{Nr}$. 22-24.)

"Likewise after the conclusion of this projected work an article of Frend appeared ("Der Dichter und das Phantasieren," Nouc Rez'tu, 2. Märzheft. I908), which expressed in brief, the fundamental idea of my work. ("Es ist von den Mythen durchaus wahrscheinlich, dass sie den entstellten Uberresten von Wunschphantasien ganzer Nationen, den Säkulartraümen der jungen Menscheit entsprechen.") 
that there is no sharp dividing line between waking phantasies and clreams. We know further, however, from Freud's researches, that the dream thoughts do not arise during the dream but are representations from previous waking periods. In the dream they only maintain a form, which differs from that in which we commonly care to express our thoughts.

Another objection, which likewise only has an apparent validity, concerns itself with the fashioning of the point of departure for our further consideration. It will be shown that the dream is an individual product, while in myths there is stored, in a way, the collective spirit of a people. One finds the comparison invalid. This error is easy to refute. If dreams originate from the emotions of individuals so there are emotions which are common to mankind. These express themselves in what Freud calls "typical" dreams. Freud has succeeded in tracing back this group of dreams to certain wishes common to all men, at the same time to point out that these same wishes lie at the bottom of certain myths. Freud's deductions regarding typical dreams may thus serve as a basis for our researches. Still it commends itself to us for our purposes, to take up the analysis of the typical dreams as a starting point. They give us opportunity to investigate the wish theory of dreams. Besides they offer, as will be shown, in certain respects, simpler situations than most other dreams. ${ }^{6}$

According to the theory of Freud there lies, at the bottom of every dream, a repressed wish in the unconscious. Every one experiences occurrences which he afterwards can never recall without a lively feeling of pain. He seeks to force such reminiscences out of his consciousness. He is not able fully to extinguish them from memory; he can only repress them into the unconscious. The repressed memories and the wishes associated with them are only apparently forgotten; that is to say they are withdrawn from spontaneous recall. So soon, however, as the function of consciousness is in any way impaired, when phantasy takes the place of logically ordered thought, as is the case in day dreaming, the dream, and under the most varied pathological sit-

${ }^{\circ}$ A further, apparently very substantial objection against the conceived relationship of dreams and myths arises from the gradual rise of myths through many generations, while the dream appears to be a transitory, short-lived structure. This objection will find its refutation in the course of our investigations. 
uations, then the repressed psychic material becomes again free. In dreams, and in the symptoms of certain psychic disturbances, the repressed wishes come again to expression. Their formerly hoped for, but delayed fulfilling is represented now in phantasy. That an important part of the repressed wishes spring from the period of childhood is one of the facts established by Freud and to which we must later come back. For the present it is sufficient to keep in mind that according to Frend's view the dream represents the fulfillment of a repressed $w$ ish and that the deepest roots of this wish lie in the childhood of the dreamer.

Frend especially emphasizes that the typical dream is descended from infantile reminiscences. Especially instructive, in this respect, are those dreams which deal with the death of near relatives. These dreams at first glance appear absolutely to contradict his view that every dream contains a wish fulfillment. Probably every one who has at some time dreamt of the death of a near relative whom he loved, will energetically assume the defensive if one assumes that he wished the death of his relative and that this secret wish came to expression in the dream. He will also emplasize that the dream was accompanied by the most painful feelings of anxiety and fright and so perhaps brought to expression an apprehension but certainly not a wish.

The theory in no way refers only to actual wishes but lays stress with great emphasis upon the significance of early infantile emotions. If one dreams of the death of a dear relative it is not at all necessary, according to Freud's teachings, to draw the conclusion that the dreamer now has such a wish; he needs only to have had it at some, perhaps remote time. To be sure one will not easily acknowledge this either.

The child, up to a certain age that shows considerable variations, is free from altruistic feelings. He lives in a naïve egoism. It is throughout erroneous to assume that the feeling of the child for its parents and brothers and sisters is from the beginning a feeling of affection. On the contrary there exists instead among the children a certain rivalry. When a second child is born the first, who had been an only child up to that time, clearly shows jealousy on account of the attention paid to it because of its helplessness. It is quite usual that a child will not give the bottle of milk to the younger, that its jealousy is stirred up when it sees the newcomer sitting on its mother's lap, which was formerly only 
its own place. It envies it its playthings, it emphasizes its own superiority when it speaks of the younger one to aclults. The younger child reacts, as soon as it is in a position to, in just such an egoistic manner. It sees in the elder an oppressor and seeks to help itself as well as its weakness makes possible. Under normal conclitions these contrasts gradually disappear to a great extent. They are never wholly rooted out in spite of all educational measures.

This hostile attitude of one child toward the other finds its expression in the wish that the other were clead. Naturally it will be disputed that a child can be so "bad" as to wish the other clearl. "Who say's that does not consider that the irlea of the child of "death' has little in common with ours except the word" (Freud). The child has no clear idea of the death of a person. It hears perhaps that this or that relative has died, is clead. For the child that only means: that person is no longer there. Daily experience teaches us how easily the child gets over the absence of a loved person. It perhaps stretches the hand forth in the rirection in which the mother has gone, it cries a little whilethen consoles itself with games or fond and no longer recalls spontaneously the going away. Older children of normal psychic constitution also get over a separation easily. In early years the child identifies death with absence. It camnot represent to itself that anyone, of whose death it has been told, will never again return. We understand now how a child in all harmlessness wishes the death of the other (or any other person). It is its rivalry: were it not so, then the occasion for rivalry and jealousy would be removed.

Between brothers and sisters this relationship of rivalry is milder than between children of the same sex, moderated by the sexual attraction. We will have to consider this point later.

New opposition arises when we consider the relation of the child to the parents from the above viewpoint. How can one assume that the child wishes the death of the father or the mother? One will at most grant this in such cases-as the abuse of the child by the parents, but will add that these are fortunately exceptional cases to whom the generalization is not applicable.

The dream of the death of the father or mother, as it occurs to everyone, contains the sought-for explanation. Freud shows from it that "the dream of the death of parents is preponderat- 
ingly common concerning that one of the pair of the same sex as the dreamer, so the son, for the most part dreams of the death of the father, the daughter of the death of the mother." This behavior is explained in part as due to an early sexual preference of the son for the mother, the daughter for the father. Out of this preference grows a certain rivalry of the son with the father for the love of the mother, and a similar situation between daughter and mother for the love of the father. The son rebels earlier or later against the patria potestas, in some cases openly, in others inwardly. At the same time the father protects his dominance against the growing son. A similar relation occurs between mother and daughter. As much as culture may soften or change this rivalry, through piety towards the parents, through love of the children, still its traces cannot be extinguished. In the most favorable cases these tendencies become repressed in the unconscious. Straightway they express themselves in dreams. Children, who are disposed to nervous or psychic disease, show, already in the early years, a very strong love or a very strong repulsion towards the parents or towards one of them. In their dreams they show these tendencies especially clearly, not less clearly, however, in the symptoms of their later disease. Frend gives very instructive examples of this kind. ${ }^{7} \mathrm{He}$ cites, among others, the case of a mentally ill girl who for the first time, in a period of confusion, expressed violent aversion for her mother. As the patient became clearer she dreamt of the death of her mother. Finally she no longer contented herself with repressing in the unconscious her feelings against her mother, but proceeded to over-compensate for that feeling by constructing a phobia, that is a morbid fear, that something might happen to the mother. The aversion became transposed, the more the patient gained composure, into an excessive apprehension about her mother's goings and comings. I have myself lately observed a quite similar case.

As complementary it may be mentioned that the dreams of adults seldom turn on the death of a child. Pregnant women, who suffer from their condition, dream of an abortion. Fathers or mothers, who in the waking state tenderly love their child, dream under special conditions that it is dead, for example, when the existence of the child interferes with the attainment of an object.

i "Traumdeutung," Seite I79 f. 
The typical dream then contains wishes which we in our waking life will not admit. In the dream life these secret wishes find expression. These wishes, common to many or to all mankind, we meet also in the myths. The first point of comparison to occupy us is, then, the common content of certain dreams and myths. We must follow Freul's lead still further. For, as mentioned, he has first analyzed a particular myth-the CEdipus saga -from the viewpoint set forth in his "Traumdeutung." I cite literally the following passage from Freul."

" Edipus, son of Laius, King of Thebes, and Jocasta, was, as a suckling, exposed, because an oracle had prophesied to the father, that the yet unborn son would be his murderer. He was saved and grew up as a king's son in a strange court, until he, uncertain of his origin, questioned the oracle himself and received from it the advice, to avoid his home, because he would be the murderer of his father and the mate of his mother. On the way from his supposed home he fell in with King Lains and slew him in a quickly stirred up dispute. Then he arrived before Thebes where he solved the ridlle of the sphinx that blocked the way and as reward was chosen king by the Thebans and given Jocasta's hand in marriage. He reigned a long time in peace and honor and begot with his unknown mother two sons and two daughters, until a pestilence broke out, which caused the Thebans again to consult the oracle. Here is the material of the tragedy of Sophocles. The messengers brought the answer that the plague would cease when the murclerer of Laius was driven from the land. The action of the story now consists only in the step by step gradual and skillfully delayed unfolling-like the work of a psychoanalysis—of the fact that Edipus himself was the murderer of Laius and also the son of the murdered King and of Jocasta."

s" Traumdeutung," Seite $180 \mathrm{f}$.

(To be continued) 